Crop Breeding and Applied Biotechnology 13: 200-202 2013

Brazilian Society of Plant Breeding. Printed in Brazil

NOTE

\title{
Genetic purity testing of pumpkin hybrid seed by ultrathin-layer isoelectric focusing
}

\author{
$\operatorname{Min} \operatorname{Yan}^{1 *}$ \\ Received 03 June 2012
}

Accepted 25 March 2013

\begin{abstract}
Ultrathin-layer isoelectric focusing of seed proteins was used to test the genetic purity of pumpkin hybrid seeds. In the pH range of 5-8, one male marker band and two female marker bands were found in the male and female parental line, respectively. Based on the male marker band and female marker bands, the genetic purity of $F_{1}$ seeds can easily be determined in the laboratory.
\end{abstract}

Key words: Prolamin, male marker band, female marker band.

\section{INTRODUCTION}

Pumpkins (Cucurbita moschata Duch.) are widely grown for commercial use in food and recreation. Most pumpkin seeds are of $F_{1}$ hybrid cultivars due to their vigor, uniformity, disease resistance, stress tolerance and good horticultural traits. To assure the uniformity and stability of field performance and yield, it is necessary to examine the genetic purity of commercial hybrid pumpkins prior to sale.

The grow out test (GOT) for genetic purity of pumpkin hybrid seeds has traditionally been conducted and is based on morphological criteria that can be influenced by environmental conditions. In addition, GOT is limited by the accuracy required, time and labor cost (Cooke 1995).

Isozyme analysis can be used for determination of genetic purity. However, this method is limited due to many factors affecting isozyme expression, including development of plant tissue and the environment. Less loci and restricted polymorphism may also affect the utility of these markers (Tanksley and Jone 1981, Arús et al. 1985).

Polymerase chain reaction (PCR)-based DNA markers exhibit great potential for differentiating varieties and identifying hybrid seed purity in pumpkin (Ferrils et al. 2003, Watcharawongpaiboon and Chunwongse 2007, Luo et al. 2008, Liu et al. 2011). However, the method is characterized by high cost and a complex experimental procedure, which is currently hard to apply in large-scale and routine commercial seed quality testing. Thus, there is a need for an assay to more simply, quickly and accurately assess genetic purity of hybrid seeds.

Gel electrophoresis is known as a technique for protein separation based on differences in physical or chemical properties, such as molecular weight or size, or electrical charge (Cooke 1995). In isoelectric focusing gel electrophoresis (IEF), proteins are separated by the differences in their electrical charges. IEF with polyacrylamide gel thickness of $0.15 \mathrm{~mm}$ is called ultrathin-layer isoelectric focusing (UTLIEF), which is a faster, safer and cheaper technique than vertical polyacrylamind gel electrophoresis for protein separation (Van den Berg 1990). This technique is accepted by the International Seed Testing Association for varietal identification and hybrid testing of maize and sunflower (ISTA 2007).

The aim of the present study was to investigate the applicability of UTLIEF for testing the genetic purity of pumpkin hybrid seeds.

\section{MATERIAL AND METHODS}

\section{Plant materials}

One pumpkin hybrid combination was used (Shengsi and its parents). The parental inbred lines and $F_{1}$ seeds were produced by normal commercial practices and provided by

${ }^{1}$ Shandong Provincial Key Laboratory of Dryland Farming Techniques, College of Agronomy and Plant Protection, Qingdao Agricultural University, Qingdao, 266109, China.*E-mail: yanmin75@163.com 
the plant breeding group at the College of Agriculture and Plant Protection, Qingdao Agricultural University.

\section{Protein extraction}

One seed of each variety was randomly chosen with 3 replications. Individual whole seeds were hulled, crushed with a grinder and placed in $1.5 \mathrm{ml}$ centrifuge tubes. Each tube was filled with $30 \%(\mathrm{v} / \mathrm{v})$ 2-chloroethanol solution with a ratio of 1:40 (v/w) with the powder and left at room temperature for $1 \mathrm{~h}$ for protein extraction. The tubes were vibrated for about $1 \mathrm{~min}$ and then centrifuged for $15 \mathrm{~min}$ at $10,000 \mathrm{rpm}$. For each sample, $10 \mu \mathrm{l}$ of seed protein was dropped into each well of the application strip and $10 \mu \mathrm{l}$ of deionized water was added.

\section{Ultrathin-layer isoelectric focusing}

The UTLIEF was conducted according to section 8.8.5 of the International Rules for testing (ISTA 2007). The polymerization solution for each gel contained $5 \mathrm{ml}$ acrylamide ( $\mathrm{T}=6.8 \%, \mathrm{C}=2.5 \%), 0.22 \mathrm{ml}$ of $\mathrm{pH} 5-8$ ampholytes (Servalyt, Germany), $0.8 \mathrm{~g}$ urea, $0.08 \mathrm{~g}$ taurine, $30 \mu \mathrm{l}$ of $20 \%(\mathrm{w} / \mathrm{v})$ ammonium peroxydisulphate and $4 \mu \mathrm{l} \mathrm{N} \mathrm{N} \mathrm{N}$ $\mathrm{N}$ '- tetramethylethylenediamine.

The gel is placed on the pre-cooled $\left(10^{\circ} \mathrm{C}\right)$ cooling plate of the horizontal electrophoresis apparatus. One anodal electrode wick and one cathodal electrode wick are soaked in the appropriate solution and placed at either side of the gel. The anode solution contained $0.332 \%(\mathrm{w} / \mathrm{v})$ aspartic acid and $0.368 \%(\mathrm{w} / \mathrm{v})$ glutamic acid, and the cathode solution contained $0.472 \%(\mathrm{w} / \mathrm{v})$ arginine, $0.364 \%(\mathrm{w} / \mathrm{v})$ lysine and $12 \%(\mathrm{v} / \mathrm{v})$ ethylenediamine. The application strip was placed about $0.5 \mathrm{~cm}$ below the buffer wick of the anode. The power supply was set at 600 volts and the $\mathrm{mA}$ adjusted to give an output voltage of approximately 120 volts once electrophoresis had started.

After $90 \mathrm{~min}$, the gel was removed and fixed in $12 \%$ $(\mathrm{w} / \mathrm{v})$ trichloroacetic acid for $20 \mathrm{~min}$, then stained by shaking in gel staining solution, which containing $0.015 \%(\mathrm{w} / \mathrm{v})$ Coomassie R250 and 0.045\% (w/v) Coomassie G250, 11\% $(\mathrm{v} / \mathrm{v})$ acetic acid, $18 \%(\mathrm{v} / \mathrm{v})$ ethanol and $71 \%(\mathrm{v} / \mathrm{v})$ water for $30 \mathrm{~min}$ and, finally, destained in a solution of $30 \%(\mathrm{v} / \mathrm{v})$ ethanol, 5\% (v/v) acetic acid and $65 \%(\mathrm{v} / \mathrm{v})$ water for 20 min. After rinsing with water, the gels were air dried at room temperature.

\section{RESULTS AND DISCUSSION}

In order to use UTLIEF for testing the genetic purity of hybrid pumpkin, it is necessary to determine the polymorphic proteins which are unique in the male and female lines. Comparing the protein patterns of the female and male with the hybrid, one or more male marker bands need to be found in the hybrid. Seeds with a protein pattern identical to the female parent are judged to be self-pollinations. Foreign pollinated seeds show a different pattern. Seeds with a different pattern may also arise due to contamination with another variety. Given the presence of male and female markers, hybrid purity can be determined.

Pumpkin seeds are rich in protein (25.2-37\%) (Lazos 1986). The main storage proteins are salt-soluble globulins, accompanied by glutelins and lesser amounts of albumins and prolamins (Marcone 1997). Different $\mathrm{pH}$ ranges of Servalyt and different extraction solutions were tested, and the $\mathrm{pH}$ range of 5-8 and 30\% 2-chloroethanol solution gave the best results (data not shown). The UTLIEF profile of seed prolamin from individual whole seeds of hybrid pumpkin and their parental lines are shown in Fig.1. One male marker (MMB1) band and two female marker bands (FMB1, FMB2) were found in the male and female lines, respectively. Based on the MMB and FMBs, the genetic purity of $F_{1}$ seeds can be easily determined in the laboratory since genuine $\mathrm{F}_{1}$ hybrids contain both the MMB1 and FMB1, FMB2. Self-pollinations $(3,9,10,18)$ contain only the FMBs (Figure 2).

Seed storage proteins are direct products of structural genes and are independent of environmental factors (Yamagata et al. 1982). And the polymorphism of seed storage proteins among varieties has been used to characterize varieties/cultivars of many important agricultural and hor-

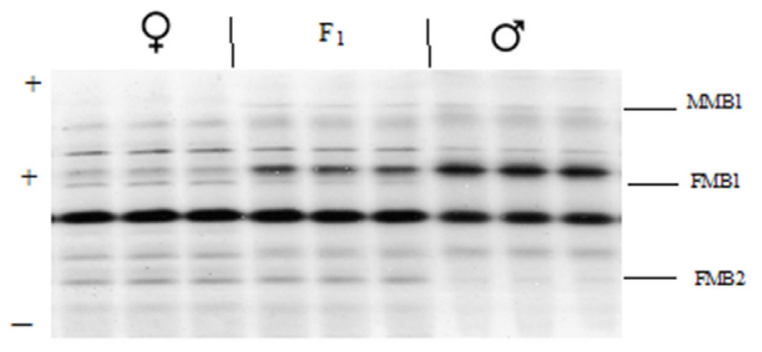

Figure 1. UTLIEF ( $\mathrm{pH} 5-8$ ) profile of protein from individual whole seeds of hybrid pumpkin combination. FMB: female marker band. MMB: male marker band. + anode; - cathode.

\section{$\left.\left.1|2| 3|4| 5|6| 7|8| 9|10| 11|12| 13|14| 15|16| 17|18| 19|20| 21|22|^{23}\right|^{24}\right|^{25}$}

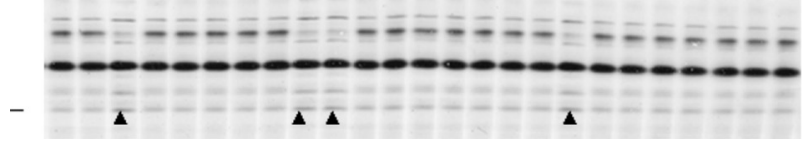

Figure 2. UTLIEF ( $\mathrm{pH} 5-8$ ) profile of protein from individual whole seeds of pumpkin hybrid seeds. $\boldsymbol{\Delta}$ are self-pollinations. + anode; - cathode. 
ticultural crops (Cooke 1988). UTLIEF of seed proteins is considered to possess greater discriminative power, requires a shorter testing time and involves lower costs than vertical polyacrylamide gel electrophoresis (Van den Berg 1990). And the technique has been used to identify many plant varieties and to test the genetic purity of hybrid seeds (Hahn and Schoberlein 1999, Wang et al. 2000, Zhao et al. 2005, Yan et al. 2006, ISTA 2007, Onwimol et al. 2010). This paper is the first report on utilization of UTLIEF in testing the genetic purity of pumpkin hybrid seeds. And the results showed that UTLIEF may also be used to test the genetic purity of pumpkin hybrid seeds.

\section{ACKNOWLEDGMENTS}

This research was funded by the Qingdao Scientific and Technological Project (08-2-1-33-nsh) and the National Natural Science Foundation of China (30900121) and the Taishan Mountain Scholar Constructive Engineering Foundation of Shandong.

\section{Teste de pureza genética de sementes de híbridos de abóbora por focalização isoeléctrica em camadas ultrafinas}

Resumo - Focalização isoeléctrica em camada ultrafina de proteinas de semente foi utilizada para testar a pureza genética de sementes de híbridos abóbora. Na amplitude de pH de 5 a 8, uma banda marcadora macho e duas bandas marcadoras femininas foram encontradas nas linhagens parentais macho e fêmea, respectivamente. Com base nas bandas marcadoras masculina e feminina, a pureza genética de sementes de $F_{1}$ pode ser facilmente determinada em laboratório.

Palavras-chave: Prolamina, banda marcadora masculina, banda marcadora feminina.

\section{REFERENCES}

Arús P, Shields CR and Orton TJ (1985) Application of isozyme electrophoresis for purity testing and cultivar identification of $F_{1}$ hybrids of Brassica oleracea. Euphytica 34: 651-657.

Cooke RJ (1988) Electrophoreiss in plant testing and breeding. In Chrambach AM, Dunn JB and Radola J (Eds) Advances in electrophoresis. VCH, New York, p.171-261.

Cooke RJ (1995) Varietal identification of crop plants. In Skerritt JH and Appels $R$ (Eds) New diagnostics in crop sciences. CAB Int, Wallingford, p. 33-63.

Ferrils M, Belen Pico M and Nuez P (2003) Genetic diversity of some accessions of Cucurbita maxima from Spain using RAPD and SBAP markers. Genetic Resources and Crop Evolution 50: 227-238.

Hahn H and Schoberlein W (1999) Identification of Festuca pratensis varieties by sodium dodecylsulphate-polyacrylamide gel electrophoresis (SDSPAGE) and ultrathin-layer isoelectric focussing (UTLIEF). Seed Science and Technology 27: 559-578.

International Seed Testing Association (ISTA) (2007) International rules for seed testing edition 2007. International Seed Testing Association, Bassersdorf.

Lazos E (1986) Nutritional, fatty acid and oil characteristics of pumpkin and melon seeds. Journal of Food Science 51: 1382-1383.

Liu Z, Sun XW Dong YJ Luo YC Zeng YX and Zuo K (2011) Hybrid purity detection of pumpkin (C.maxima L.) varieties with SRAP and RSAP markers. Acta Agricultural Boreali-occidentalis Sinnica 20: $124-128$.

Luo FQ, Sun XW Dong YJ Liu ZF and Yang HB (2008) Identification of Hybrid Seed Purity in Pumpkin using Random Amplified Polymorphic DNA (RAPD). Acta Agricultural Boreali-Sinica 23: 63-66.
Marcone FM, Kakuda Y and Yada RY (1997) Salt-soluble seed globulins of various dicotyledonous and monocotyledonous plants- I . Isolationpurification and characterization. Food Chemistry 62: 27-47.

Onwimol D, Chanpreme S and Thongket T (2010) Seed storage protein extraction and gel $\mathrm{pH}$ gradient for cucumber varietal identification via an ultrathin-layer isoelectric focusing technique. Kasetsart J (National Science) 44: 902-911.

Tanksley SD and Jones RA(1981) Applications of alcohol dehydrogenase allozymes in testing the genetic purity of $F_{1}$ hybrids of tomato. HortScience 16: 179-181.

Van den Berg BM (1990) Inbred testing of tomato (Lycopersicon esculentum $\mathrm{L}$.) $\mathrm{F}_{1}$ varieties by ultrathin-thin layer isoelectric focusing of seed protein. Electrophoresis 11: 824-829.

Wang XF, Knoblauch R and Leist N (2000) Varietal discrimination of tomato (Lycopersicon esculentum $\mathrm{L}$.) by ultrathin-thin layer isoelectric focusing of seed protein. Seed Science and Technology 28: 521-526.

Watcharawongpaiboon N and Chunwongse J (2007) Development of microsatellite markers from an enriched genomic library of pumpkin (Cucurbita moschata L.). Songklanakarin Journal of Science and Technology 29: 1217-1223.

Yamagata H, Sugimoto T, Tanaka K and Kasai Z (1982) Biosynthesis of storage proteins in developing rice seeds. Plant Physiology 70: 1094-1100.

Yan M, Ye H and Wang XF (2006) Investigation into the feasibility of assessing the hybridity of immature rice grains. Seed Science and Technology 34: 1-8.

Zhao T, Yan M, Lu YP, Huang J and Wang XF (2005) Genetic purity testing of two-line hybrid rice seeds by ultrathin-layer isoelectric focusing of proteins. Seed Science and Technology 33: 45-52. 